\title{
Unprotected anal intercourse among Iranian intra-venous
} drug users

\section{Parvaneh Mirabi ${ }^{1}$, Mosaieb Yarmohmmadi Vasel ${ }^{2}$, Babak Moazen ${ }^{3}$, Mahmoud Sehat $^{4}$, Majid Rezazadeh ${ }^{5}$ and Khodabakhsh Ahmadi 6 *}

1 Department of Midwifery, Zanjan Branch, Islamic Azad University, Zanjan, Iran

${ }^{2}$ Department of Psychology, Bu-Ali Sina University, Hamedan, Iran

${ }^{3}$ Medicine and Health Promotion Institute, Tehran, Iran

${ }^{4}$ Universal Network for Health Information Dissemination and Exchange (UNHIDE), Tehran, Iran

${ }^{5}$ AIDS Prevention and Control Committee, Welfare Organization State, Tehran, Iran

${ }^{6}$ Behavioral Sciences Research Center, Baqiyatallah Medical Sciences University, Tehran, Iran

Edited by:

Shervin Assari, University of Michigan School of Public Health, USA

Reviewed by:

Shervin Assari, University of Michigan School of Public Health, USA

Arezoo Shajiei, Mashhad University of Medical Sciences, Iran

*Correspondence:

Khodabakhsh Ahmadi, Baqiyatallah University of Medical Sciences, Mollasadra Street, 19945-546, Tehran, Iran

e-mail:khodabakhsh.ahmadi@ gmail.com
Purpose: To assess the prevalence and associated factors of unprotected anal intercourse among Iranian male heterosexual Intra-Venous Drug Users (IDUs).

Methods: In a cross-sectional study 360 male heterosexual IDUs were sampled from streets of eight different geographical parts of Iran. Variables such as socio-demographics, HIV knowledge (10 items), and HIV attitude (16 items) were entered to a logistic regression to determine the predictors of unprotected anal intercourse during the past month.

Results: From all, 20.8\% reported unprotected anal intercourse during the past month. HIV knowledge was not significantly different among IDUs with and without unprotected anal intercourse. High age lodds ratio $(\mathrm{OR})=0.954,95 \%$ confidence intervals $(\mathrm{Cl})=0.916$ 0.992] was associated with a lower likelihood of unprotected anal intercourse, while being not married $(\mathrm{OR}=2.301,95 \% \mathrm{Cl}=1.151-4.601)$, and high perceived HIV risk (OR $=1.776$, $95 \% \mathrm{Cl}=1.376-2.290)$ were associated with a higher likelihood of unprotected anal intercourse.

Conclusion: Although the results might not be generalizable to all Iranian IDUs, this study findings may still be helpful for design and implementation of public health programs in Iran to prevent sexual transmission of HIV through IDUs.

Keywords: risk behaviors, unprotected sex, anal intercourse, Iran, intra-venous drug users

\section{INTRODUCTION}

People who engage in unprotected sex may have different motivations. Some people may want to show intimacy, romance, and trust to a sex partner through practicing unprotected sex (1). Some other people may decline to use condom to express their masculinity and individual choice. Other individuals may practice unprotected sex to achieve more sexual pleasure (2). Making more money is another possible reason for practice of unprotected sex among sex workers (3).

Considerable evidence has suggested that likelihood of HIV transmission by unprotected anal intercourse is several times higher than through unprotected vaginal intercourse (4). Although anal intercourse might be less common than oral or vaginal sex (6), it is still a common sexual mode among heterosexual couples (5).

Having more sex partners (10) and shared injecting (11) introduce Intra-Venous Drug Users (IDUs) as a group high risk for HIV and AIDS (7-9). Through sex with general population, injecting drug users become a source for HIV transmission to the community. This may spread HIV from a concentrated epidemic to a non-concentrated one. Unfortunately, current harm reduction policies have failed to decrease sexually transmitted infections prevalence among IDUs (11).
Size of HIV infections and IDUs are increasing rapidly in Iran (12). Unfortunately, there are very few studies assessing high-risk sexual behaviors among Iranian IDUs. Much less has been done to determine the prevalence and associated factors of unprotected anal intercourse among male IDUs in Iran.

The current study aimed to assess prevalence and associated factors of unprotected anal intercourse among Iranian male heterosexual injecting drug users.

\section{MATERIALS AND METHODS DESIGN AND SETTING}

With a cross-sectional design, this study was a secondary analysis of a data set of IDUs in eight different geographical parts of Iran: Tehran, Shiraz, Esfahan, Arak, Ahvaz, Rasht, Mashhad, and Ardebil. The survey with the unique sample was conducted by the Behavioral Sciences Research Center, Baqiyatallah University of Medical Sciences during 2009. Other reports have been extracted from this data set focusing on causes of condom non-use and syringe sharing $(11,12$, Rezazade and Ahmadi, under review).

\section{ETHICAL PROCEDURES}

Informed consent was obtained from all participants after they were verbally assured that the information would be kept 
confidential, especially from the correctional setting. All checklists and questionnaires were anonymous. Study protocol was approved by the ethical review committee of the Baqiyatallah University (13, Ahmadi and Rezazade, accepted).

\section{PARTICIPANTS AND SAMPLING}

Participants were male IDUs recruited from streets in the above listed cities by snowball sampling over a 7 month period in 2009 . Every participant who reported at least one drug injection during his life time was eligible. Heterosexuality was cleared by this question: "How many of your sexual partners were male and how many were female"? Those who reported sex with female(s) during their life time and declined sex with male partner(s) were considered as heterosexual.

\section{PROCESS}

Structured interviews were conducted by research assistants who were trained through workshops. Each interview lasted up to $60 \mathrm{~min}$. No financial incentives were offered to the participants, however, condom and sterile injection equipment were delivered as compensation.

\section{MEASURES}

Our questionnaire included socio-demographic data (i.e., age, gender, marital status, educational level, housing, and occupational situation), family data (i.e., number of siblings, number of children, living status, and parental living status), history of childhood trauma (i.e., experiencing violence by family members, level of family intimacy), HIV attitude (16 items such as perceived HIV risk, eagerness to learn about HIV, changing some behaviors such as drug use and sexual habits, self efficiency about highrisk behaviors), HIV knowledge (10 items about condom use, sex with a healthy looking person, HIV transmission routs), and sexual behaviors (including number of sexual intercourses, number of unprotected sexual acts, number of sex with drug users and injectors, and reason of condom non-use during the past 1 and 6 months).

\section{MAIN OUTCOME}

The following single item was applied to determine unprotected anal intercourse: "During the past month, how many times had you unprotected anal sex"? Similar outcome has been assessed using one question, before $(14,15)$. We dichotomized the outcome to having and not having any unprotected anal sex.

\section{STATISTICAL ANALYSIS}

The data obtained in the Statistical Package for the Social Sciences 17 (SPSS Inc., IL, USA) for Windows. For bi-variate analysis, Man Whitney and Chi-square tests were used. Logistic regression model was applied to determine associated factors of unprotected anal intercourse during the past month. Odds Ratios (ORs) and 95\% Confidence Intervals (CI) are reported. $p$-Value $<0.05$ considered significant.

\section{RESULTS}

Of the 360 IDUs who included in this study, 55\% were single, 93.1\% had at least primary education, $7.8 \%$ reported living at friends or relative's house, $34.7 \%$ were unemployed, and $19.2 \%$ reported living alone. Thirty one point two percent reported themselves being exposed to intensive violence by their family members (much and too much), and $33.1 \%$ thought that will never acquire HIV in their life time, and $58.6 \%$ had never participated in educational HIV prevention courses (Tables 1 and 2).

Seventy five heterosexual IDUs (20.8\%) reported at least one anal intercourse during the past month. In bi-variate analysis, being non-married $(\mathrm{OR}=0.404,95 \% \mathrm{CI}=0.231-0.706)$ was associated with an increased likelihood of this outcome. Median perceived HIV risk was significantly higher among those with unprotected anal intercourse in comparison with those without this behavior (Median $=3, \mathrm{Q} 1=2, \mathrm{Q} 3=4 \mathrm{vs}$. Median $=2, \mathrm{Q} 1=1$, $\mathrm{Q} 3=3, p<0.001)$.

HIV knowledge was not significantly different among IDUs with and without unprotected anal intercourse (Median $=5$,

Table 1 | Socio-demographic data among Iranian heterosexual male IDUs $(n=360)$.

\begin{tabular}{|c|c|c|}
\hline Data & $n$ & $\%$ \\
\hline \multicolumn{3}{|l|}{ SOCIO-DEMOGRAPHIC DATA } \\
\hline \multicolumn{3}{|l|}{ Marital status } \\
\hline Single & 198 & 55.0 \\
\hline Married & 158 & 43.9 \\
\hline Missing & 4 & 1.1 \\
\hline \multicolumn{3}{|l|}{ Educational level } \\
\hline Uneducated & 25 & 6.9 \\
\hline Primary school & 74 & 20.6 \\
\hline Some secondary school & 187 & 51.9 \\
\hline High school diploma & 51 & 14.2 \\
\hline Associated degree & 18 & 5.0 \\
\hline Bachelor's degree and higher & 2 & 0.6 \\
\hline Missing & 3 & 0.8 \\
\hline \multicolumn{3}{|l|}{ Housing } \\
\hline Personal & 94 & 26.1 \\
\hline Rental & 73 & 20.3 \\
\hline Father's house & 139 & 38.6 \\
\hline Friend's house & 18 & 5.0 \\
\hline Relatives house & 10 & 2.8 \\
\hline Missing & 26 & 7.2 \\
\hline \multicolumn{3}{|l|}{ Occupational status } \\
\hline Student & 6 & 1.7 \\
\hline Self-employe & 174 & 48.3 \\
\hline Employe & 4 & 1.1 \\
\hline Retired & 3 & 0.8 \\
\hline Homemaker & 2 & 0.6 \\
\hline Home service & 10 & 2.8 \\
\hline Work at private companies & 14 & 3.9 \\
\hline Unemployed & 125 & 34.7 \\
\hline Missing & 14 & 3.9 \\
\hline \multicolumn{3}{|l|}{ Living status } \\
\hline Alone & 72 & 20.1 \\
\hline With family members & 260 & 82 \\
\hline With others & 26 & 7.3 \\
\hline Missing & 2 & 0.6 \\
\hline
\end{tabular}


Table 2 | Descriptive statistics of childhood trauma and HIV attitude among male Iranian heterosexual IDUs $(n=360)$.

\begin{tabular}{llr}
\hline & $\boldsymbol{n}$ & $\%$ \\
\hline CHILDHOOD TRAUMA & & \\
Exposure to violence & & \\
Never & 58 & 16.1 \\
Little & 76 & 21.1 \\
Sometimes & 108 & 30.0 \\
Much & 56 & 15.6 \\
Too much & 56 & 15.6 \\
Missing & 6 & 1.7 \\
HIV ATTITUDE & & \\
Perceived HIV risk & & \\
Not at all & 119 & 33.1 \\
A little & 97 & 26.9 \\
Some & 93 & 25.8 \\
High & 27 & 7.5 \\
Very high & 17 & 4.7 \\
Missing & 7 & 1.9 \\
Participation in HIV prevention courses & & \\
Never & 211 & 13.3 \\
Once & 65 & 18.1 \\
Twice & 30 & 8.3 \\
More & 48 & \\
Missing & 6 & 1.7 \\
\hline & & \\
\hline
\end{tabular}

$\mathrm{Q} 1=2, \mathrm{Q} 3=7$ vs. Median $=5, \mathrm{Q} 1=2, \mathrm{Q} 3=7, p=0.653)$. In logistic regression, lower age $(\mathrm{OR}=0.954,95 \% \mathrm{CI}=0.916-0.992)$, being not married $(\mathrm{OR}=2.301,95 \% \mathrm{CI}=1.151-4.601)$, and higher perceived HIV risk $(\mathrm{OR}=1.776,95 \% \mathrm{CI}=1.376-2.290)$ and were associated with higher likelihood of unprotected anal intercourse (Table 3).

\section{DISCUSSION}

About $21 \%$ of Iranian heterosexual IDUs report at least one unprotected anal sex during the past month; however higher age, being unmarried, and higher perceived HIV risk were associated with a higher prevalence of this behavior. This study sheds light to a less researched area of sexual behavior of IDUs, the unprotected anal sex. Existing literature has mostly focused on vaginal intercourse and its associated factors, rather than other types of sex.

This considerable amount of unprotected anal intercourse reported by IDUs might be explained by the fact that some people even don't consider anal sex as sex, and if they think that anal sex is not sex, they may not feel need to condom use. It is notable that practice of heterosexual anal intercourse is highly affected by culture and ethnicity (16). Anal intercourse among IDUs especially heterosexual IDUs needs more research.

Being not married $(\mathrm{OR}=2.301)$ increased the likelihood of unprotected anal intercourse among Iranian heterosexual IDUs. Most of studies $(17,18)$ but not all (19) confirms our finding due to deviant, substance-abusing sources, and having multiple sex partners as well as offering an economic security and social integration to non-married people. In general population, well designed studies have shown considerable positive effects of marriage on health behaviors (18). This possible health impact has been explained by two theories. "Selection theory" suggesting healthier people more likely to get married and "protection theory" talking about providing a shield against health risk behaviors (20). However negative effects of being married on drug outcomes have been explained with this term: "If one side of a couple has drug problems, it is likely that other side has problems too" (17).

We found more unprotected anal intercourse among younger IDUs ( $\mathrm{OR}=0.945$ for age). In terms of HIV infection, most studies have suggested younger people as more vulnerable group. For all types of sex, a lower frequency is expected to occur in higher ages, and anal sex is not an exception. Sexual desire is known to decrease by aging (22). This however does not mean that older IDUs do not need attention for their sexual risk behaviors. Anti-impotence and erectile-dysfunction drugs has extended the sex life to higher age and may buffer age related sexual limitations (21). Some researchers believe that "older people become sexually active in a world where there were no AIDS" and compare to younger people, they might be less aware of the consequences of unprotected sex, making them less accustomed to using condoms (21).

Unexpectedly, higher perceived HIV risk $(\mathrm{OR}=1.776)$ was associated with a higher likelihood of unprotected anal intercourse among Iranian IDUs. There are contradictory findings about association of perceived HIV risk and high-risk behaviors. Although most scholars have suggested more preventive practices by increasing perceived HIV risk $(23,24)$, interestingly some others have shown opposite results (25), which is in line with our finding. This controversy may be caused by measurement incompatibility, subpopulation and behavioral distinctions, and unexamined critical factors constructing perceived risk (25).

In our study, HIV knowledge did not predict unprotected anal intercourse among heterosexual Iranian IDUs. Most studies haven't entered knowledge as a possible predictor, or have found no association in this regard (26-28). Among that few studies which have reported a relation between awareness level and highrisk behaviors $(29,30)$, one has not even controlled the effect of confounding variables (30). Literature also has documented no impact of merely media campaigns on HIV risk behavior (31). These evidences weaken the role of HIV knowledge promotion programs in prevention of HIV infection through decreasing high-risk behaviors among IDUs.

Results of this study and some others (21) highlight the need of more attention to older IDUs as a high-risk group which raises the risk of HIV infection and other sexual transmitted diseases among uninfected people. As previously suggested (26), our study confirms that among existing factors which possibly affect HIV transmission, HIV knowledge seems less important. We suggest policy makers to focus on socioeconomics variables such as marital status, as it has been suggested by other researchers before (26-28). All in all, our findings should be implemented as a part of "combined prevention programs" (32).

Considerable amount of missing data, including $4 \%$ no answer unprotected anal intercourse is one of the limitations of this study. Being cross-sectional, causative associations were not conclusive. Under-reporting is a common consequence of self-reported data collection due to social desirability bias or concerns of confidentiality (33). We were not able to assess relationship 
Table 3 | Predictors of unprotected anal intercourse based on a logistic regression among Iranian male heterosexual IDUs.

\begin{tabular}{|c|c|c|c|c|}
\hline \multirow[t]{2}{*}{ Variable } & \multirow[t]{2}{*}{$d f$} & \multirow[t]{2}{*}{$\operatorname{Exp}(B)$} & \multicolumn{2}{|c|}{$95 \% \mathrm{Cl}$ for $\exp (\mathrm{B})$} \\
\hline & & & Upper & Lower \\
\hline Age & 1 & 0.954 & 0.916 & 0.992 \\
\hline Not married & 1 & 2.301 & 1.151 & 4.601 \\
\hline Perceived HIV risk & 1 & 1.776 & 1.376 & 2.290 \\
\hline
\end{tabular}

between injection frequency and our outcome. The study was also limited to measure individual level factors (34). Current study only enrolled male IDUs. We already know that there are important gender differences in sexual behaviors, substance use, and their correlated factors (35-40).

However, two reasons represent our findings more important, firstly the stressed role of male partner in transmission of HIV because of their more high-risk sexual behaviors in comparison with females (41), and secondly, more probability of HIV transmission due to anal intercourse than vaginal intercourse (2). Thus, the study is hoped to provide a better picture from substance use (42-47) and blood born infections (48-55) and their associated factors in developing countries such as Iran.

Despite efforts to better understand HIV risk profile of IDUs in Iran, what we do not know is much more than what we know

\section{REFERENCES}

1. Jones R, Oliver M. Young urban women's patterns of unprotected sex with men engaging in HIV risk behaviors. AIDS Behav (2007) 11(6):812-21. doi:10.1007/s10461006-9194-3

2. Klein H. Sexual orientation, drug use preference during sex, and HIV risk practices and preferences among men who specifically seek unprotected sex partners via the internet. Int J Environ Res Public Health (2009) 6(5):1620-35. doi:10. 3390/ijerph6051620

3. Reed E, Gupta J, Biradavolu M, Devireddy V, Blankenship KM. The context of economic insecurity and its relation to violence and risk factors for HIV among female sex workers in Andhra Pradesh, India. Public Health Rep (2010) 125(Suppl 4):81-9.

4. World Health Organization. AIDS and Men Who Have Sex with Men. UNAIDS Technical Update. (2000). Available from: http://whqlibdoc.who.int/unaids/ 2000/a62375_eng.pdf

5. Baggaley RF, White RG, Boily MC. HIV transmission risk through anal intercourse: systematic review, meta-analysis and implications for HIV prevention. Int J Epidemiol (2010) 39(4):1064-5. doi:10.1093/ ije/dyq057
6. Hensel DJ, Fortenberry JD, Orr DP. Factors associated with event level anal sex and condom use during anal sex among adolescent women. $J$ Adolesc Health (2010) 46(3):232-7. doi:10.1016/j. jadohealth.2009.06.025

7. Strathdee SA, Philbin MM, Semple SJ, Pu M, Orozovaich P, Martinez $\mathrm{G}$, et al. Correlates of injection drug use among female sex workers in two Mexico-U.S. border cities. Drug Alcohol Depend (2008) 92(1-3):132-40. doi:10.1016/j. drugalcdep.2007.07.001

8. Feng C, Des Jarlais D. HIV among drug users in China. Science (2002) 298(5596):1171. doi:10. 1126/science.298.5596.1171c

9. Des Jarlais D, Caraël M. AIDS 1999. Behavioral and social science: overview. AIDS (1999) 13(Suppl A):S235-7.

10. Iguchi MY, BuxJr DA, Kushner $\mathrm{H}$, Lidzin V. Correlates of HIV risk among female sex partners of injecting drug users in a high-seroprevalence area. Eval Program Plann (2001) 24(2):175-85. doi:10.1016/S0149-7189(01) 00009-X

11. Gyarmathy VA, Neaigus A. The relationship of sexual dyad and personal network characteristics and individual attributes to unprotected sex among young injecting drug

(56-64). Further research should explore profile of risk behaviors that result in transmission of HIV and other blood born infections. Such research also provides information about how substance use and sexual behavior influence wellbeing and quality of life of IDUs $(65,66)$.

To conclude, about $21 \%$ of Iranian male heterosexual IDUs report unprotected anal intercourse during the previous month. Iranian male IDUs who are younger, not married, and report higher HIV perceived risk are at higher risk of engagement in unprotected anal intercourse.

\section{ACKNOWLEDGMENTS}

This survey has been conducted by Behavioral Sciences Research Center, Baqiyatallah Medical Sciences University, and welfare organization, Iran.

users. AIDS Behav (2009) 13(2): 196-206. doi:10.1007/s10461-0079285-9

12. Razzaghi EM, Movaghar AR, Green TC, Khoshnood K. Profiles of risk: a qualitative study of injecting drug users in Tehran, Iran. Harm Reduct J (2006) 18(3):12. doi:10.1186/14777517-3-12

13. Ahmadi K, Rezazade M, Nafarie M, Moazen B, Yarmohmmadi Vasel M, Assari S. Unprotected sex with injecting drug users among Iranian female sex workers: unhide HIV risk study. AIDS Res Treat (2012) 2012:651070. doi:10.1155/ 2012/651070

14. Zea MC, Reisen CA, Poppen PJ, Bianchi FT. Unprotected anal intercourse among immigrant latino MSM: the role of characteristics of the person and the sexual encounter. AIDS Behav (2009) 13(4): 700-15. doi:10.1007/s10461008-9488-8

15. Dudley MG, Rostosky SS, Korfhage BA, Zimmerman RS. Correlates of high-risk sexual behavior among young men who have sex with men. AIDS Educ Prev (2004) 16(4):328-40. doi:10.1521/aeap.16. 4.328.40397

16. Roye CF, Krauss BJ, Silverman PL. Prevalence and correlates of heterosexual anal intercourse among Black and Latina female adolescents. J Assoc Nurses AIDS Care (2010) 21(4):291-301. doi:10.1016/j.jana.2009.12.002

17. Stein JA, Nyamathi A, Ullman JB, Bentler PM. Impact of marriage on HIV/AIDS risk behaviors among impoverished, at-risk couples: a multilevel latent variable approach. AIDS Behav (2007) 11(1): 87-98. doi:10.1007/s10461-0059058-2

18. Osler M, McGue M, Lund R, Christensen K. Marital status and twins' health and behavior: an analysis of middle-aged Danish twins. Psychosom Med (2008) 70(4):482-7. doi:10.1097/PSY

0b013e31816f857b

19. McIntyre P. Married Adolescents: No Place of Safety. World Health Organization and United Nations Population Fund (2006). Available from: http: //whqlibdoc.who.int/publications/ 2006/9241593776_eng.pdf

20. Prior PM, Hayes BC. Marital status and bed occupancy in health and social care facilities in the United Kingdom. Public Health (2001) 115(6):401-6. doi:10.1016/ S0033-3506(01)00486-3

21. Jurberg C. Unprotected sex has no age. Bull World Health Organ (2009) 87(3):165-6. doi:10.2471/ BLT.09.010309 
22. Hayes RD, Dennerstein L, Bennett CM, Koochaki PE, Leiblum SR, Graziottin A. Relationship between hypoactive sexual desire disorder and aging. Fertil Steril (2007) 87(1):107-12. doi:10.1016/j. fertnstert.2006.05.071

23. Bailey SL, Ouellet LJ, MackesyAmiti ME, Golub ET, Hagan H, Hudson SM, et al. Perceived risk, peer influences, and injection partner type predict receptive syringe sharing among young adult injection drug users in five U.S. cities. Drug Alcohol Depend (2007) 91(Suppl 1):S18-29. doi:10.1016/j. drugalcdep.2007.02.014

24. Ford CL, Daniel M, Miller WC. High rates of HIV testing despite low perceived HIV risk among AfricanAmerican sexually transmitted disease patients. J Natl Med Assoc (2006) 98(6):841-4.

25. Ward EG, Disch WB, Schensul JJ, Levy JA. Understanding low-income, minority older adult self-perceptions of HIV risk. J Assoc Nurses AIDS Care (2010) 22(1):26-37. doi:10.1016/j.jana.2010.05.002

26. Ferrer L, Cianelli R, Guzman E, Cabieses B, Irarrázabal L, Bernales $\mathrm{M}$, et al. Chilean university students: knowledge and concern about HIV/AIDS. J Assoc Nurses AIDS Care (2007) 18(5):51-6. doi: 10.1016/j.jana.2007.07.001

27. DiClemente RJ, Brown LK, Beausoleil NI, Lodico M. Comparison of AIDS knowledge and HIV-related sexual risk behaviors among adolescents in low and high AIDS prevalence communities. J Adolesc Health (1993) 14(3):231-6. doi:10. 1016/1054-139X(93)90011-D

28. Strathdee SA, Patrick DM, Archibald CP, Ofner M, Cornelisse PG, Rekart M, et al. Social determinants predict needlesharing behaviour among injection drug users in Vancouver, Canada. Addiction (1997) 92(10):1339-47. doi:10.1111/j.1360-0443.1997. tb02852.x

29. López R, Bravo MJ, Barrio G, Lardelli P, Bueno A, de la Fuente L. HIV-transmission knowledge in drug users from outpatient facilities in Spain. A national survey. Drug Alcohol Depend (1994) 34(3):181-90. doi:10.1016/03768716(94)90155-4

30. Sowell RL, Seals BF, Phillips KD. Knowledge and risk behaviors of people seeking HIV antibody testing at a community site. J Assoc Nurses AIDS Care (1996) 7(3):33-41. doi: 10.1016/S1055-3290(96)80075-6
31. Becker MH, Joseph JG. AIDS and behavioral change to reduce risk: a review. Am J Public Health (1988) 78(4):394-410. doi:10.2105/AJPH. 78.4.394

32. Des Jarlais DC, Arasteh K, McKnight C, Hagan H, Perlman DC, Torian LV, et al. HIV infection during limited versus combined HIV prevention programs for IDUs in New York city: the importance of transmission behaviors. Drug Alcohol Depend (2010) 109(1-3):154-60. doi:10. 1016/j.drugalcdep.2009.12.028

33. Niccolai LM, Kershaw TS, Lewis JB, Cicchetti DV, Ethier KA, Ickovics JR. Data collection for sexually transmitted disease diagnoses: a comparison of self-report, medical record reviews, and state health department reports. Ann Epidemiol (2005) 15(3):236-42. doi:10.1016/j. annepidem.2004.07.093

34. Assari S. Multilevel approach to intimate partner violence research and prevention. Int J Prev Med (2013) 4(5):616-7.

35. Kazemi-Saleh D, Pishgou B, Farrokhi F, Assari S, Fotros A, Naseri $H$. Gender impact on the correlation between sexuality and marital relation quality in patients with coronary artery disease. J Sex Med (2008) 5(9):2100-6. doi:10.1111/j. 1743-6109.2007.00724.x

36. Tavallaii SA, Fathi-Ashtiani A, Nasiri M, Assari S, Maleki P, Einollahi B. Correlation between sexual function and postrenal transplant quality of life: does gender matter? J Sex Med (2007) 4(6):1610-8. doi:10.1111/j.1743-6109.2007. 00565.x

37. Mohammadkhani P, Forouzan AS, Khooshabi KS, Assari S, Lankarani MM. Are the predictors of sexual violence the same as those of nonsexual violence? A gender analysis. J Sex Med (2009) 6(8):2215-23. doi:10.1111/j.1743-6109.2009. 01338.x

38. Mohammadkhani P, Khooshabi KS, Forouzan AS, Azadmehr H, Assari S, Lankarani MM. Associations between coerced anal sex and psychopathology, marital distress and non-sexual violence. J Sex Med (2009) 6(7):1938-46. doi:10.1111/j. 1743-6109.2009.01273.x

39. Kazemi-Saleh D, Pishgoo B, Farrokhi F, Fotros A, Assari S. Sexual function and psychological status among males and females with ischemic heart disease. J Sex Med (2008) 5(10):2330-7. doi:10.1111/j. 1743-6109.2008.00788.x

40. Kazemi-Saleh D, Pishgou B, Assari S, Tavallaii SA. Fear of sexual intercourse in patients with coronary artery disease: a pilot study of associated morbidity. J Sex Med (2007) 4(6):1619-25. doi:10.1111/j. 1743-6109.2007.00619.x

41. Krantz SR, Lynch DA, Russell JM. Gender-specific profiles of selfreported adolescent HIV risk behaviors. J Assoc Nurses AIDS Care (2002) 13(6):25-33. doi:10.1177/ 1055329002238023

42. Angoorani H, Narenjiha H, Tayyebi B, Ghassabian A, Ahmadi G, Assari S. Amphetamine use and its associated factors in body builders: a study from Tehran, Iran. Arch Med Sci. (2012) 8(2):362-7. doi:10.5114/ aoms.2012.28566

43. Khooshabi K, Forouzan SA, Ghassabian A, Assari S. Is there a gender difference in associates of adolescents' lifetime illicit drug use in Tehran, Iran? Arch Med Sci (2010) 6(3):399-406. doi:10.5114/ aoms.2010.14263

44. Khedmat H, Karami Narenjiha H, Rafiey H, Jahani MR, Assari S, Moharamzad Y, et al. Substancedependent professional drivers in Iran: a descriptive study. Traffic Inj Prev (2009) 10(3):227-30. doi:10. 1080/15389580902849017

45. Rafiey H, Narenjiha H, Shirinbayan P, Noori R, Javadipour M, Roshanpajouh $\mathrm{M}$, et al. Needle and syringe sharing among Iranian drug injectors. Harm Reduct J (2009) 6:21. doi:10.1186/14777517-6-21

46. Daneshmandan N, Narenjiha $\mathrm{H}$ Tehrani K, Assari S, KhoddamiVishteh HR. Initiation to the first drug use among substancedependent persons in Iran. Subst Use Misuse (2011) 46(9): 1124-41. doi:10.3109/10826084. 2010.490971

47. Alavian SM, Zarchi AAK, Javadipour M, Assari S, Keshvari $M$, Behnava B. Self report cigarette smoking and some correlates in Iranian asymptomatic HBV carriers. Arch Med Sci (2007) 3(3):240-4

48. Tavallaii SA, Nemati Merat S, Rezvan $H$, Nouraie M, Jamali A, Assari $\mathrm{S}$, et al. The prevalence of hepatitis $\mathrm{B}$ surface antigen and anti-hepatitis B core antibody in Iran: a populationbased study. Arch Iran Med (2009) 12(3):225-31.

49. Ahmadnezhad E, Sepehrvand N, Hatami S, FayyazJahani F, Ahmadnezhad S, Karamyyar M, et al. Thematic analysis of iranian female adolescents' perceptions about HIV/AIDS: a qualitative study. Int $J$ Prev Med (2013) 4(4):484-8.
50. Alavian SM, Izadi M, Zare AA, Lankarani MM, Assari S, Vardi MM. Survey of the level of antiHBs antibody titer in vaccinated Iranian general dentists. Spec Care Dentist (2008) 28(6):265-70. doi:10.1111/j.1754-4505.2008. 00052.x

51. Ghorbani G, Alavian S, Assari S. Seroepidemiology of hepatitis A virus in Iranian soldiers in 2006: do they need vaccination? Hepat Mon (2007) 7(1):7-9.

52. Ghorbani GA, Alavian SM, Esfahani AA, Assari S. Seroepidemiology of hepatitis E virus in Iranian soldiers. Hepat Mon (2007) 7(3): 123-6.

53. Behnava B, Assari S, Amini M, Hajibeigi B, Manzouri Jouybari $H$, Alavian SM. HBV DNA viral load and chronic hepatitis infection in different stages. Hepat Mon (2005) 5(4):123-7.

54. Alavian SM, Mansouri S, Abouzari M, Assari S, Bonab MS, Miri SM. Long-term efficacy of hepatitis B vaccination in healthcare workers of Oil Company Hospital, Tehran, Iran (1989-2005). Eur J Gastroenterol Hepatol (2008) 20(2):131-4. doi:10.1097/MEG. 0b013e3282f1cc28

55. Merat S, Rezvan H, Nouraie M, Jamali A, Assari S, Abolghasemi H, et al. The prevalence of hepatitis $B$ surface antigen and anti-hepatitis B core antibody in Iran: a populationbased study. Arch Iran Med (2009) 12(3):225-31.

56. Noroozi M, Nedjat S, Golestan B, Majdzadeh R. What are differences between non-injecting and injecting drug addicts? Int J Prev Med (2012) 3(6):414-9.

57. Kassaian N, Adibi P, Kafashaian A, Yaran M, Nokhodian Z, Shoaei P, et al. Hepatitis $C$ virus and associated risk factors among prison inmates with history of drug injection in Isfahan, Iran. Int J Prev Med (2012) 3(Suppl 1):S156-61.

58. Shokoohi M, Baneshi MR, Haghdoost AA. Size estimation of groups at high risk of HIV/AIDS using network scale up in Kerman, Iran. Int J Prev Med (2012) 3(7):471-6.

59. Nobari RF, Meshkati M, Ataei B, Yazdani MR, Heidari K, Kassaian $\mathrm{N}$, et al. Identification of patients with hepatitis $C$ virus infection in persons with background of intravenous drug use: the first community announcement-based study from Iran. Int J Prev Med (2012) 3(Suppl 1):S170-5.

60. Nasrullah Concentrated M. HIV epidemic in Pakistan: 
an opportunity to prevent generalized epidemic. Int $J$ Prev Med (2012) 3(12):824-6. doi:10.4103/2008-7802.104851

61. Haghdoost A, Karamouzian M. Zero new HIV infections, zero discrimination, and zero AIDSrelated deaths: feasible goals or ambitious visions on the occasion of the world AIDS day? Int J Prev Med (2012) 3(12):819-23. doi:10. 4103/2008-7802.104850

62. Alavian SM. On the occasion of the world hepatitis day: world hepatitis day and our achievements and responsibilities in Iran. Int $J$ Prev Med (2012) 3(7):437-9.

63. Hassannejad R, Kassaian N, Ataei B, Adibi P. High risky behaviors among intravenous drug users in Isfahan, Iran: a study for hepatitis $\mathrm{C}$ harm reduction programs. Int J Prev Med (2012) 3(Suppl 1):S73-8.

64. Nokhodian Z, Meshkati M, Adibi P, Ataei B, Kassaian N, Yaran M, et al. Hepatitis $\mathrm{C}$ among intravenous drug users in Isfahan, Iran: a study of seroprevalence and risk factors. Int J Prev Med (2012) 3(Suppl 1):S131-8.

65. Assari S, Jafari M. Quality of life and drug abuse. In: Preedy VR, Watson RR, editors. Handbook of Disease Burdens and Quality of Life Measures. Heidelberg: Springer (2010). p. 3691-704.

66. Azizabadi Farahani M, Assari S. Quality of life and sexuality. In:
Preedy VR, Watson RR, editors. Handbook of Disease Burdens and Quality of Life Measures. Heidelberg: Springer (2010). p. 3457-73.

Conflict of Interest Statement: The authors declare that the research was conducted in the absence of any commercial or financial relationships that could be construed as a potential conflict of interest.

Received: 06 August 2013; paper pending published: 12 August 2013; accepted: 28 August 2013; published online: 26 September 2013.

Citation: Mirabi P, Yarmohmmadi Vase M, Moazen B, Sehat M, Rezazadeh $M$ and Ahmadi K (2013) Unprotected anal intercourse among Iranian intra-venous drug users. Front. Public Health 1:34. doi: 10.3389/fpubh.2013.00034

This article was submitted to HIV and AIDS, a section of the journal Frontiers in Public Health.

Copyright (C) 2013 Mirabi, Yarmohmmadi Vasel, Moazen, Sehat, Rezazadeh and Ahmadi. This is an open-access article distributed under the terms of the Creative Commons Attribution License (CC $B Y)$. The use, distribution or reproduction in other forums is permitted, provided the original author(s) or licensor are credited and that the original publication in this journal is cited, in accordance with accepted academic practice. No use, distribution or reproduction is permitted which does not comply with these terms. 